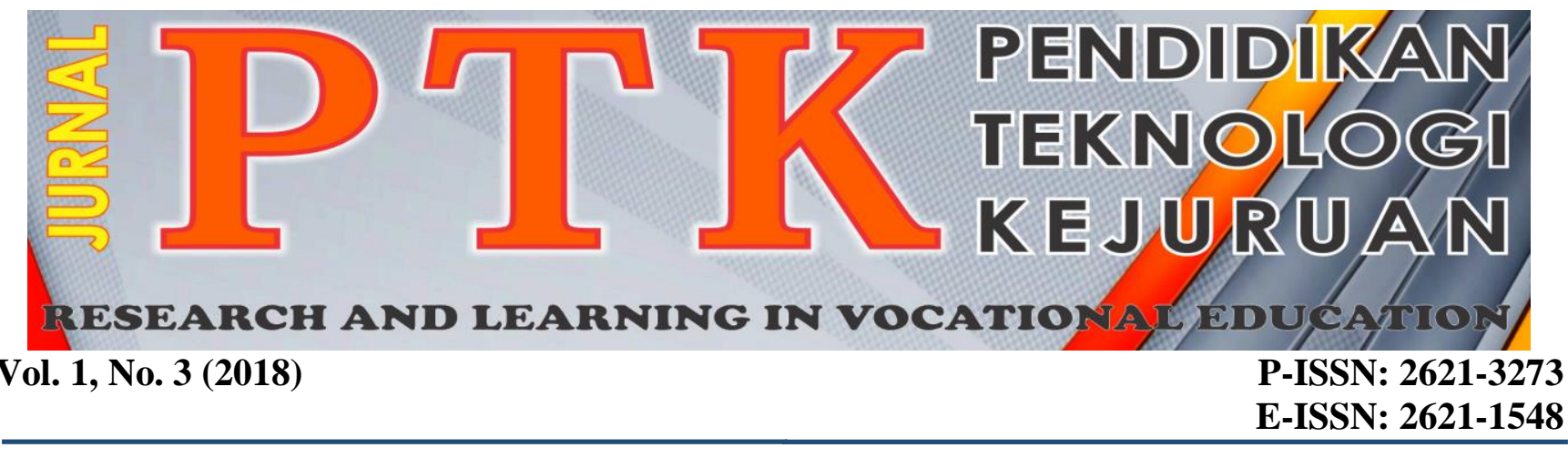

\title{
PENGEMBANGAN PERANGKAT PEMBELAJARAN BERBASIS MODEL PJBL PADA MATA DIKLAT TEKNIK DIGITAL
}

\author{
Yondriadi $^{*}$, Nizwardi Jalinus ${ }^{2}$, Nurhasan $\operatorname{Syah}^{3}$ dan Bulkia Rahim ${ }^{4}$ \\ ${ }^{1}$ SMK Negeri 1 Merapi Timur, ${ }^{2}$ Universitas Negeri Padang \\ "Corresponding author, e-mail: yon.driadi@yahoo.com
}

\begin{abstract}
Abstrak - Berdasarkan observasi, yang menjadi permasalahan yaitu: Kecendrungan proses pembelajaran selama ini guru mata diklat teknik digital menggunakan metode ceramah sedangkan mata pelajaran ini merupakan salah satu mata pelajaran produktif, karena itu guru harus mampu menerapkan metode pembelajaran yang cocok dan perangkat pembelajaran yang digunakan. Pelaksanaan pembelajaran, guru belum mempunyai inisiatif untuk mengembangkan sebuah perangkat pembelajaran sesuai dengan konten atau materi pembelajaran sehingga siswa hanya diberikan pelajaran sebatas bahan yang ada dibuku teks, kondisi ini membuat siswa menjadi jenuh dan pembelajaran bersifat monoton, hal ini berakibat pada kegiatan pembelajaran menjadi kurang menarik, tidak optimal bagi siswa dan kurang efektifnya pembelajaran, serta bagaimana menghubungkan antara apa yang dipelajari dengan kehidupan nyata dan bagaimana memanfaatkan pengetahuan yang diperoleh untuk menunjang kehidupannya. Tujuan penelitian untuk menghasilkan perangkat pembelajaran berbasis proyek yang valid, praktis dan efektif agar layak digunakan di lapangan dan mengetahui bentuk perangkat pembelajaran berbasis model PjBL. Model penelitian yang digunakan adalah pengembangan model ADDIE. Model ini terdiri dari 5 tahap pengembangan yaitu Analysis, Design, Development, Implementation, Evaluation. Subjek penelitian adalah siswa kelas XI Jurusan Elektronika Industri SMK Negeri 1 Merapi Timur. Jenis data yaitu data primer dimana data yang diberikan oleh dosen ahli dan siswa. Instrumen pengumpul data berbentuk angket. Teknik analisis data deskriptif untuk mendeskripsikan kevalidan, kepraktisan dan keefektifan perangkat pembelajaran berbasis model PjBL. Berdasarkan temuan penelitian ini disimpulkan bahwa perangkat pembelajaran berbasis proyek ini valid, praktis dan efektif untuk dimanfaatkan sebagai perangkat pembelajaran berbasis proyek pada mata diklat Teknik Digital.
\end{abstract}

Kata kunci：Perangkat Pembelajaran, Teknik Digital, Validitas, Praktikalitas, Efektivitas.

Abstract-Based on the observation, the problem is: The tendency of the learning process during this time the eye teacher of digital technique training using direct learning method (lecture) while this subject is one of productive subjects, therefore the teacher must be able to apply suitable learning method and learning device used. Implementation of learning, teachers do not have the initiative to develop a learning device in accordance with the content or learning materials so that students are only given lesson limited to existing materials in textbook, this condition makes students become saturated and learning is monoton, this result in less interesting learning activities, not optimal for students and less effective learning, and how to connect between what is learned with real life and how to utilize the knowledge gained to support his life. The objective of the research is to produce a valid, practical and effective project-based learning tool to be feasible in the field and to know the form of projectbased learning tools. The research model used is the development of ADDIE model. This model consists of 5 development stages: analysis, design, development, implementation and evaluation. The subjects of the study were the students of XI class of Electronics Industry Department of SMK Negeri 1 Merapi Timur. The type of data is primary data where the data provided by expert lecturers and students. Data collection instrument in the form of a questionnaire. Descriptive data analysis techniques to describe the validity, practicality and effectiveness of project-based learning tools. Based on the findings of this study, it is concluded that the project-based learning tool is valid, practical and effective to be utilized as a PjBL model tool in the eyes of Digital Engineering.

Keywords： Learning Devices, Digital Techniques, Validity, Practicality, Effectiveness

\section{Pendahuluan}

Tercapaiannya tujuan pembelajaran dalam proses pembelajaran ditandai dengan adanya perubahan tingkah laku. Perubahan tingkah laku tersebut baik menyangkut perubahan yang bersifat pengetahuan (kognitif), keterampilan (psikomotor) maupun yang menyangkut nilai dan sikap (afektif). Terdapat banyak faktor yang mempengaruhi tercapainya tujuan pembelajaran. Mengemukakan ada dua faktor utama yang mempengaruhi hasil belajar yaitu: yang pertama faktor internal yang mencakup faktor jasmaniah, intelengensi, motivasi, perhatian, minat, bakat dan kesiapan [1]. kedua faktor eksternal yang 
terdiri dari faktor keluarga, masyarakat, kurikulum dan model pembelajaran. Model pembelajaran yang diberikan kepada siswa. Jika siswa mudah menerima materi pelajaran dan menguasainya, maka siswa akan lebih termotivasi dan maju dalam belajar.

Guru salah satu faktor penting untuk mewujudkan proses dan tujuan dari proses pembelajaran itu sendiri, terutama dalam menentukan model dan strategi pembelajaran yang dapat mengarahkan siswa belajar dengan lebih bermakna dan menyenangkan, sehingga dapat menjadikan siswa mampu berpartisi aktif, mandiri, meningkatkan keterampilan, dan berkreasi atau mengekspresikan ide-ide yang ada dalam pikirannya [2]. Model pembelajaran berfungsi pula sebagai pedoman bagi para perancang pembelajaran dan para guru dalam merencanakan aktivitas belajar mengajar. Dalam penerapannya, guru diberikan kebebasan dalam merencanakan, melaksanakan dan menilai kurikulum serta hasil belajar siswa pada saat menyampaikan kompetensi inti dan kompetensi dasar sebagai cermin penguasaan dan pemahaman terhadap mata diklat yang dipelajari.

Salah satu mata diklat yang diajarkan di Sekolah Menengah Kejuruan (SMK khususnya di paket keahlian Elektronika Industri adalah Teknik Digital. Dalam pembelajaran Teknik digital siswa dituntut untuk aktif dan dapat menguasai materi sebelumnya yang mereka pelajari karena materi yang disajikan dalam pembelajaran Teknik digital saling berhubungan dan saling melengkapi antara satu materi dengan materi lainnya. Sehingga dengan model pembelajaran yang dikembangkan dapat mewujudkan siswa yang mampu mandiri, berkreasi dengan ide-ide atau ilmu yang dimilikinya, salah satunya dengan mengembangkan model pembelajaran.

Berdasarkan pengamatan dan observasi yang telah dilakukan di jurusan Elektronika Industri di SMKN 1 Merapi Timur, Kecendrungan proses pembelajaran selama ini guru mata diklat teknik digital menggunakan metode pembelajaran langsung (ceramah) sedangkan mata pelajaran ini merupakan salah satu mata pelajaran produktif, karena itu guru harus mampu menerapkan metode pembelajaran yang cocok dan perangkat pembelajaran yang digunakan.

Perangkat pembelajaran adalah alat atau perlengkapan untuk melaksanakan proses yang memungkinkan pendidik dan peserta didik melakukan kegiatan pembelajaran [3]. Pelaksanaan pembelajaran, guru belum mempunyai inisiatif untuk mengembangkan sebuah perangkat pembelajaran sesuai dengan konten atau materi pembelajaran sehingga siswa hanya diberikan pelajaran sebatas bahan yang ada dibuku teks, kondisi ini membuat siswa menjadi jenuh dan pembelajaran bersifat monoton, hal ini berakibat pada kegiatan pembelajaran menjadi kurang menarik, tidak optimal bagi siswa dan kurang efektifnya pembelajaran, serta bagaimana menghubungkan antara apa yang dipelajari dengan kehidupan nyata dan bagaimana memanfaatkan pengetahuan yang diperoleh untuk menunjang kehidupannya. Penerapan pembelajaran yang aktif menuntut kemampuan guru merancang dan mengembangkan perangkat pembelajaran yang dapat membantu siswa maupun guru dalam proses pembelajaran.

Faktor pendidikan yang kurang sesuai dalam penyampaian materi dan pemilihan perangkat pembelajaran menyebabkan tujuan pembelajaran kurang dapat diterima secara sempurna oleh siswa. Faktor pendidikan disini diartikan seperti fasilitas yang dibutuhkan dalam proses pembelajaran seperti perangkat pembelajaran yang digunakan oleh guru. Hal ini pentingnya pemilihan perangkat pembelajaran merupakan bahan yang dibutuhkan oleh guru dalam interaksi dengan siswa.

Proses belajar siswa dipengaruhi oleh perangkat pembelajaran baik di sekolah maupun di rumah. Umumnya mahasiswa hanya fokus belajar di sekolah saja, setelah di rumah fokus belajar mereka berkurang karena faktor lain seperti bekerja bermain dan lain-lain. Hal ini mempengaruhi proses belajar siswa, pemahaman siswa di dalam mendalami pembahasan pembelajaran sehingga berdampak pada hasil belajar siswa.

Mengemukakan bahwa belajar merupakan proses penting bagi perubahan perilaku setiap orang dan belajar itu mencakup segala sesuatu yang dipikirkan dan dikerjakan oleh seseorang[4]. Belajar merupakan suatu proses, suatu kegiatan dan bukan suatu hasil atau tujuan [5]. Belajar bukan hanya mengingat, akan tetapi lebih luas dari itu, yaitu mengalami. Pembelajaran adalah proses interaksi siswa dengan guru dan sumber belajar pada suatu lingkungan belajar. Proses pembelajaran perlu direncanakan, dilaksanakan, dinilai, dan diawasi agar terlaksana secara efektif dan efisien [6].

Proses pembelajaran diselenggarakan secara interaktif, inspiratif, menyenangkan, menantang, memotivasi peserta didik untuk berpartisipasi aktif, serta memberikan ruang yang cukup bagi prakarsa, kreativitas, dan kemandirian sesuai dengan bakat, minat, dan perkembangan fisik serta psikologis [7].

Prinsip belajar yang digunakan pada pembelajaran di SMK ada beberapa macam yaitu: 1). Prinsip belajar sambil bekerja yaitu kegiatan pembelajaran dimana guru harus banyak memberi kesempatan kepada anak untuk melakukan praktek atau percobaan atau menemukan sesuatu melalui 
pengamatan, penelitian, dan sebagainya. 2). Prinsip individualisasi yaitu prinsip dimana guru perlu mengenal kemampuan awal, gaya belajar, dan karakteristik setiap anak secara mendalam baik dari segi kemampuan maupun ketidakmampuannya dalam menyerap materi pelajaran. 3). Prinsip menemukan, guru perlu mengembangkan strategi pembelajaran yang mampu memancing anak untuk terlibat secata aktif baik fisik, mental, sosial, dan/atau emosional. 4). Prinsip pemecahan masalah, guru hendaknya sering mengajukan berbagai persoalan/problem yang ada di lingkungan sekitar, dan anak dilatih untuk merumuskan, mencari data, menganalisis, dan memecahkannya sesuai dengan kemampuan [7].

Kurangnya bahan ajar atau sumber pembelajaran merupakan salah satu bagian penyebab dari tidak maksimalnya dari pemahaman siswa di dalam pembelajaran mata Diklat Teknik Digital. Untuk itu perlu menambah referensi dan memperbanyak bahan ajar Teknik Digital untuk menunjang kemampuan siswa di dalam memahami pelajaran.

Hasil pengamatan penelitian dan data ketuntasan hasil belajar sebenarnya banyak faktor yang membuat hasil belajar siswa kurang memenuhi standard KKM (Kriteria Ketuntasan Minimal) salah satunya penyebabnya adalah penerapan pembelajaran yang telah ada. Terutama untuk mata diklat Teknik digital yang mendominasi pembelajaran praktek, proses pembelajaran terfokus pada tingkatan kemampuan siswa untuk saat belajar saja, membuat siswa menjadi jenuh dan bersifat monoton. Maka sangat dibutuhkan perangkat pembelajaran penunjang untuk pembelajaran.

Perangkat pembelajaran dapat mempertinggi kualitas proses belajar siswa antara lain bahan pengajaran akan menarik perhatian siswa sehingga dapat menumbuhkan motivasi belajar siswa. Hal ini sangat penting bagi guru untuk memilih Perangkat pembelajaran yang digunakan. Pemilihan media pembelajaran yang kurang sesuai menyebabkan mahasiswa cepat bosan, tidak mendengarkan guru sehingga siswa kurang menyukai mata pelajaran tersebut. Hal ini berpengaruh pada hasil belajar siswa dan motivasi belajar siswa.

Perangkat pembelajaran berbasis proyek pada mata diklat Teknik Digital ini belum ada sebelumnya. Jurusan Teknik Elektronika Industri hanya terdapat berbagai macam buku tentang Teknik Digital yang ada di perpustakaan dan media pembelajaran berupa Jobsheet. Hal ini membuat siswa kurang belajar mandiri yang hanya mengandalkan penjelasan dari guru, buku dan dari layanan internet. Melalui kegiatan berbasis project based learning $(\mathrm{PjBL})$ model mahasiswa memiliki motivasi yang tinggi untuk mengembangkan kompetensinya, karena tugas proyek mahasiswa merupakan proyek nyata yang diangkat dari masalah yang berkembang dimasyarakat [8], [9], [10].

Berbagai macam-macam buku Teknik Digital yang ada di perpustakaan memiliki kelebihan yaitu membahas dalam ruang lingkup yang luas, terinci, terstruktur dan terarah. Tetapi di dalam buku tidak tersedianya pedoman, tidak adanya lembaran kegiatan siswa, tidak adanya lembaran kerja, tidak adanya kunci lembaran kerja, tidak adanya lembaran tes, tidak adanya kunci lembaran tes pembelajaran. Hal ini tidak dapat dilihat tingkat pemahaman siswa di dalam materi pembelajaran mata diklat Teknik Digital.

Jobsheet sebagai media pembelajaran pada mata diklat Teknik Digital yang tersedia belum memadai di dalam penguasaan dan pemahaman teori siswa. Karena di dalam Jobsheet memiliki kelemahan seperti hanya terdiri dari gambar kerja dan diikuti langkah-langkah kerja operasional serta dilengkapi lembar evaluasi hasil praktek siswa. Di dalam Jobsheet tidak adanya materi pendukung untuk membantu siswa di dalam belajar. Hal ini mengakibatkan tidak sempurnanya siswa di dalam memahami materi.

Mengatasi permasalahan tersebut di atas maka perlunya menambah referensi di dalam pembelajaran siswa seperti perangkat pembelajaran sebagai media pembelajaran. Perangkat pembelajaran memiliki kelebihan-kelebihan untuk pembelajaran karna di dalam perangkat pembelajaran tersdiri dari: 1). Pedoman, berisi petunjuk-petunjuk agar mengajar secara efesien serta memberikan penjelasan tentang jenis-jenis kegiatan yang harus dilakukan oleh siswa, waktu untuk menyelesaikan perangkat pembelajaran, 2). Lembaran kegiatan siswa, adanya pembahasan materi sesuai dengan tujuan instruksional yang akan dicapai seperti keselamatan kerja siswa di dalam pratikum, materi setiap pembelajaran sehingga membantu siswa di dalam pratikum Teknik Digital. 3). Lembaran kerja, menyertai lembaran kegiatan siswa yang digunakan untuk menjawab atau mengerjakan soal-soal tugas atau masalahmasalah yang harus dipecahkan. 4). Kunci lembaran kerja. 5). Lembaran tes. 6). Kunci lembaran tes. Sehingga dengan terstukturnya pembelajaran baik materi maupun langkah kerja siswa di dalam perangkat pembelajaran maka di harapkan akan membawa dampak terhadap pemahaman siswa di dalam pembelajaran. Maka perangkat pembelajaran sangat penting di dalam pembelajaran Teknik Digital.

Permasalahan yang terjadi yang berkaitan dengan perangkat pembelajaran diupayakan untuk mencoba mengembangkan sebuah media berbentuk perangkat pembelajaran berbasis projek mata diklat Teknik 
Digital. Sudah adanya, buku Teknik Digital, Jobsheet mata diklat Teknik Digital maka perlu dilakukannya pengembangan perangkat pembelajaran.

\section{METODE}

Penelitian dan pengembangan (Research and Development). Penelitian pengembangan adalah metode penelitian yang digunakan untuk menghasilkan produk tertentu dan menguji keefektifan produk tersebut [11]. Prosedur pengembangan bahan ajar dengan menggunakan model ini menggunakan model pengembangan model ADDIE (Analysis-Design-DevelopImplement-Evaluate).

Teknik pengumpulan data berupa angket (kuesioner). Teknik analisis data terdiri dari analisis validitas, analisis praktikalitas dan analisis efektifitas. Analisis validitas adalah hasil validasi melalui angket terhadap perangkat pembelajaran berbasis proyek pada mata diklat Teknik Digital dari validator terhadap seluruh aspek (materi, format dan penyajian) yang dinilai. Analisis praktikalitas diperoleh dari hasil penilaian melalui angket terhadap perangkat pembelajaran berbasis proyek pada mata diklat Teknik Digital dari siswa. Analisis efektivitas dari perangkat pembelajaran berbasis proyek pada mata diklat Teknik Digital ditentukan dengan cara melihat pencapaian ketuntasan hasil belajar siswa dengan menggunakan perangkat pembelajaran berbasis proyek pada mata diklat Teknik Digital yang diperoleh saat penelitian dan dibandingkan dengan kelas yang tidak menggunakan perangkat pembelajaran berbasis proyek pada mata diklat Teknik Digital.

\section{HASIL DAN PEMBAHASAN}

\section{A. Hasil Pengembangan}

Tahapan-tahapan yang dilakukan untuk menghasilkan produk perangkat pembelajaran berbasis proyek pada mata diklat Teknik Digital adalah sebagai berikut:

\section{Tahap Analysis (Analisis)}

a. Observasi

Observasi yang dilakukan di SMK Negeri 1 Merapi Timur pada mata diklat Teknik Digital didapatkan masalah yaitu selama ini proses pembelajaran Teknik Digital tidak menggunakan Perangkat Pembelajaran sebagai sumber belajar yang bisa dijadikan acuan oleh siswa. Saat proses pembelajaran guru lebih banyak menjelaskan pelajaran tanpa banyak melibatkan siswa, cara penyajian materi yang kurang menarik oleh guru membuat siswa menjadi kurang termotivasi untuk mengikuti pelajaran. Masalah lain yang dihadapi siswa adalah kurangnya sumber referensi tentang buku mata pelajaran Teknik Digital, ketersediaan sumber belajar berupa buku-buku untuk mata pelajaran Teknik Digital di perpustakaan SMK Negeri 1 Merapi Timur hanya ada 1 sumber referensi. Permasalahan diatas menyebabkan proses pembelajaran yang berlangsung masih berpusat kepada guru, hal ini dapat dilihat bahwa siswa bersikap pasif, hanya mengandalkan guru untuk mendapatkan materi pembelajaran, sehingga pembelajaran berlangsung secara monoton, dan akhirnya membuat siswa mudah menjadi bosan dan jenuh.

\section{b. Analisis Kurikulum}

Kurikulum 2013 di SMK diharapkan mampu menciptakan generasi yang produktif, kreatif, dan inovatif. Kurikulum 2013 merupakan pendidikan berbasis karakter. Pendidikan karakter memiliki makna lebih tinggi dari pendidikan moral, karena pendidikan karakter tidak hanya berkaitan dengan masalah benar-salah, tetapi bagaimana menanamkan kebiasaan tentang hal-hal yang baik dalam kehidupan, sehingga peserta didik memiliki kesadaran, dan pemahaman yang tinggi, serta kepedulian dan komitmen untuk menerapkan kebajikan dalam kehidupan sehari [10]. Dengan demikian dapat dikatakan bahwa karakter merupakan sifat alami seseorang dalam merespon situasi secara bermoral.

Analisis kurikulum ini mengacu pada silabus mata pelajaran Teknik Digital yang ada di SMK Negeri 1 Merapi Timur pada semester ganjil, agar pembelajaran yang akan dihasilkan tidak menyimpang dari tujuan pembelajaran. Topik yang dikembangkan pada silabus mata pelajaran Teknik Digital, yaitu sebagai berikut:

Tabel 1. Topik dan Pokok Bahasan Teknik Digital berbasis proyek pada semester Ganjil

\begin{tabular}{ll}
\hline No & Topik/Pokok Bahasan \\
\hline 1 & Gate Dasar dan Tambahan \\
2 & Flip Flop \\
3 & Serial Input Pararel Output, Kegiatan Belajar \\
4 & Pararel Input Pararel Output \\
5 & BCD To 7 Segment \\
6 & Multiplekser \\
7 & Decoder \\
\hline
\end{tabular}

c. Identifikasi Materi yang Dibutuhkan Perangkat Pembelajaran

Identifikasi materi yang dibutuhkan Perangkat Pembelajaran dilakukan dengan bertukar pendapat dengan guru mata pelajaran Teknik Digital mengenai beberapa materi pembelajaran Teknik 
Digital. Setelah bertukar pendapat dengan guru mata pelajaran, langkah selanjutnya yaitu mengumpulkan informasi tentang materi yang dibutuhkan. Informasi ini diperoleh dari silabus satuan pendidikan SMK Negeri 1 Merapi Timur pada mata pelajaran Teknik Digital.

\section{Tahap Perancangan (Design)}

Temuan tahapan ini merupakan perancangan Perangkat Pembelajaran sesuai dengan rancangan yang telah dibuat. Hasil rancangan Perangkat Pembelajaran tersebut terdiri dari:

a. Rancangan halaman sampul Perangkat Pembelajaran Teknik Digital Berbasis Proyek.

b. Rancangan halaman judul Perangkat Pembelajaran Teknik Digital Berbasis Proyek.

c. Rancangan halaman kata pengantar Perangkat Pembelajaran Teknik Digital Berbasis Proyek.

d. Rancangan halaman peta kedudukan Perangkat Pembelajaran Teknik Digital Berbasis Proyek.

e. Rancangan halaman pendahuluan Perangkat Pembelajaran Teknik Digital Berbasis Proyek.

f. Rancangan Kegiatan Belajar 1 Sampai Dengan Kegiatan Belajar 7.

g. Rancangan Perangkat Pembelajaran

Terdapat rancangan Peragkat Pembelajaran bebasis Proyek, terdapat 7 pembelajaran yaitu 1). Gate Dasar dan Tambahan, Kegiatan Belajar 2). Flip Flop, Kegiatan Belajar 3). Serial Input Pararel Output, Kegiatan Belajar 4). Pararel Input Pararel Output, Kegiatan Belajar 5). BCD To 7 Segment, Kegiatan Belajar 6). Multiplekser dan Kegiatan Belajar 7). Decoder. Ketujuh pembelajaran dengan Peragkat Pembelajaran tersebut mempunyai karakteristik rancangan yang sama. Masing-masing Peragkat Pembelajaran memiliki komponenkomponen yang sama yaitu tujuan pembelajaran, materi pembelajaran, Rangkuman, Tes Formatif, Soal latihan, Lembaran kerja siswa, Jawaban tes formatif. Tes Formatif pada setiap kegiatan belajar terdiri atas soal pilihan ganda dan essay, masingmasing 5 soal. Latihan pada setiap kegiatan belajar terdiri 5 butir soal.

Rancangan Peragkat Pembelajaran kegiatan satu yang membahas pembelajaran Teknik Digital Berbasis Proyek. Berikut ini adalah penjelasan tentang materi pada kegiatan pembelajaran:

\section{a. Kegiatan pembelajaran 1}

Rancangan Peragkat Pembelajaran kegiatan pembelajaran 1 yang membahas Gate Dasar dan Tambahan. Berikut ini adalah penjelasan tentang materi pada kegiatan pembelajaran 1

1. Gate Dasar

2. Gate Tambahan
3. Praktikum Nand Gate

4. Praktikum Not Gate

5. Praktikum And Gate

6. Praktikum Nor Gate

7. Praktikum Or Gate

8. Praktikum Xor Gate

9. Praktikum Xnor Gate

b. Kegiatan pembelajaran 2

Rancangan Peragkat Pembelajaran kegiatan pembelajaran 6 yang membahas FLIP FLOP. Berikut ini adalah penjelasan tentang materi pada kegiatan pembelajar 6:

1. Piranti SR-FF

2. Piranti D- FF

3. Piranti JK- FF

4. Piranti T- FF

5. Praktikum RS Flip Flop

6. Praktikum Flip Flop

7. Praktikum JK Flip-Flop

8. Praktikum Toggle Flip Flop

c. Kegiatan pembelajaran 3

Rancangan Peragkat Pembelajaran kegiatan pembelajaran 3 yang membahas Serial Input Pararel Output. Berikut ini adalah penjelasan tentang materi pada kegiatan pembelajaran 3:

1.. Serial Input Pararel Output

2. . Praktikum SIPO 74LS164

\section{d. Kegiatan pembelajaran 4}

Rancangan Peragkat Pembelajaran kegiatan pembelajaran 4 yang membahas Pararel Input Pararel Output. Berikut ini adalah penjelasan tentang materi pada kegiatan pembelajaran 4:

1.. Pararel Input Pararel Output

2. . Praktikum PIPO 74ALS574

e. Kegiatan pembelajaran 5

Rancangan Peragkat Pembelajaran kegiatan pembelajaran 5 yang membahas $\mathrm{BCD}$ TO 7 segment. Berikut ini adalah penjelasan tentang materi pada kegiatan pembelajaran 5:

1. BCD TO 7 segment

2. Praktikum BCD To 7 Segment

\section{f. Kegiatan pembelajaran 6}

Rancangan Peragkat Pembelajaran kegiatan pembelajaran 2 yang membahas Multiplekser. Berikut ini adalah penjelasan tentang materi pada kegiatan pembelajaran 2:

1. Multiplekser ( MUX)

2. Demultiplexer

3. Cara kerja Multiplexer dan Demultiplexer

4. Praktikum Multiplekser 
g. Kegiatan pembelajaran 7

Rancangan Peragkat Pembelajaran kegiatan pembelajaran 7 yang membahas DECODER. Berikut ini adalah penjelasan tentang materi pada kegiatan pembelajaran 7:

1. Demultiplexer (Dekoder)

2. Praktikum Decoder 2 To 4

3. Praktikum Decoder 3 to 8

4. Praktikum Decoder 4 To 16

h. Rancangan halaman Uji Kompetensi

i. Rancangan halaman daftar pustaka Perangkat Pembelajaran Perangkat Pembelajaran Teknik Digital Berbasis Proyek

j. Rancangan halaman glosarium Perangkat Pembelajaran Teknik Digital berbasis Proyek

k. Rancangan Halaman Penutup Perangkat Pembelajaran Teknik Digital berbasis Proyek

\section{B. Data Uji Efektifitas}

\section{Hasil Belajar Koknitif}

\section{a). Hasil Pretest}

Hasil belajar Teknik Digital dilihat dari hasil prestest. Hasil belajar kelas kontrol dari 32 orang siswa didapat hasil nilai rata-rata untuk prestest $(42$, 95). Hasil belajar kelas eksperimen dari 32 orang siswa didapat hasil rata-rata untuk prestest $(42,15)$. Berikut ini adalah Tabel rata-rata hasil belajar siswa kelas kontrol dan kelas eksperimen untuk test pretest:

Tabel 2. Rata-rata Hasil Belajar Postest Siswa Kelas Kontrol dan Eksperimen

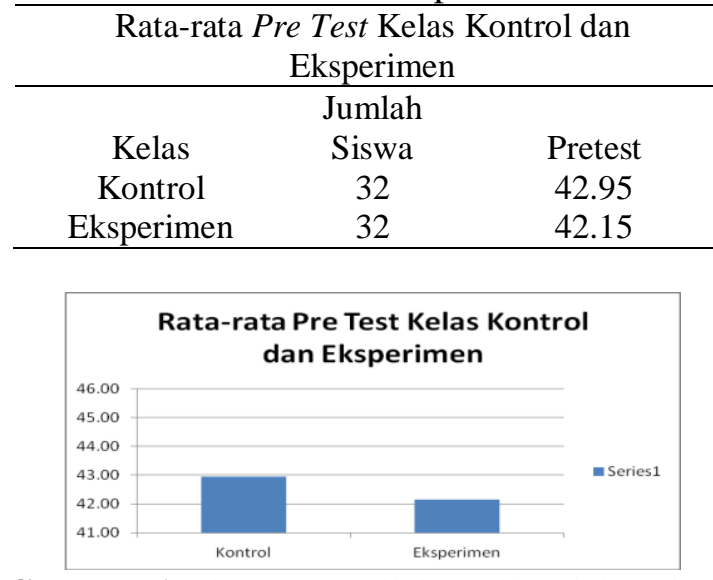

Gambar 1 Histogram Nilai Hasil Belajar Siswa Kelas Kontrol dan Eksperimen tes prestest

\section{b). Hasil Postest}

Hasil belajar Teknik Digital dilihat dari hasil postest siswa kelas kontrol (kelas tidak menggunakan Perangkat Pembelajaran) dan kelas eksperimen (menggunakan Perangkat
Pembelajaran). Hasil belajar kelas kontrol (tidak menggunakan Perangkat Pembelajaran) dari 32 orang siswa didapat hasil nilai rata-rata untuk postest $(74,80)$. Hasil belajar kelas eksperimen (menggunakan Perangkat Pembelajaran) dari 32 orang siswa didapat hasil rata-rata untuk postest (90,09). Berikut ini adalah Tabel rata-rata hasil belajar siswa kelas kontrol (kelas tidak menggunakan Perangkat Pembelajaran) dan kelas eksperimen (menggunakan Perangkat Pembelajaran):

Tabel 3. Rata-rata Hasil Belajar Postest Siswa Kelas Kontrol dan Eksperimen

\begin{tabular}{|c|c|c|}
\hline \multicolumn{3}{|c|}{ Rata-rata Postest Kelas Kontrol dan Eksperimen } \\
\hline Kelas & Jumlah Siswa & Pretest \\
\hline Kontrol & 32 & 74.80 \\
\hline Eksperimen & 32 & 90.09 \\
\hline
\end{tabular}

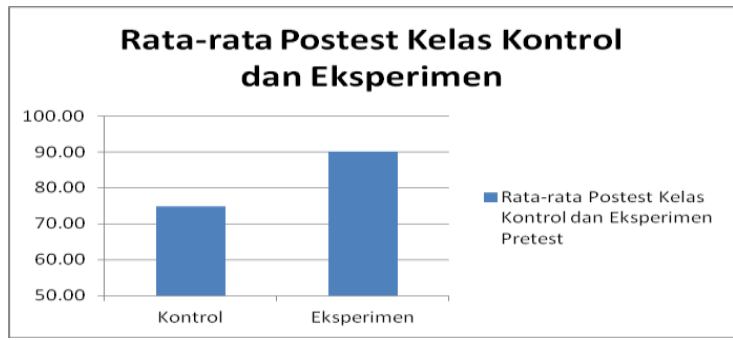

Gambar 2 Histogram Peningkatan Nilai Hasil Belajar Siswa Kelas Kontrol dan Eksperimen

\section{c). Peningkatan Hasil Pretest dan Postest}

Tabel 4. Rata-rata Hasil Belajar pretest dan Postest Siswa Kelas Kontrol dan Eksperimen

\begin{tabular}{|} 
Rata-rata pretest dan Pos Test Kelas Kontrol \\
dan Eksperimen
\end{tabular}

Gambar 3 Histogram Peningkatan Nilai Hasil Belajar Siswa preetest dan posttest Kelas Kontrol dan Eksperimen

\section{d). Uji-t}

Uji ini digunakan untuk mengetahui ada atau tidaknya perbedaan rata-rata antara dua kelompok 
sampel yang tidak berhubungan. Sampel adalah mengalami dua perlakuan yang berbeda, dan data yang digunakan biasanya berskala interval atau rasio. Uji-t digunakan untuk menguji bagaimana pengaruh masing-masing variabel bebasnya secara sendiri-sendiri terhadap variabel terikatnya.

Tabel 5. Uji-t Nilai Pos Test Kelas Kontrol dan Kelas Eksperimen

\begin{tabular}{|c|c|c|c|c|c|c|c|c|}
\hline & \multicolumn{5}{|c|}{ Paired Differences } & \multirow{2}{*}{$\begin{array}{c}\mathrm{t} \\
\text { Mean }\end{array}$} & \multirow{2}{*}{\begin{tabular}{|c|} 
Df \\
$\begin{array}{c}\text { Std. } \\
\text { Deviation }\end{array}$
\end{tabular}} & \multirow{2}{*}{$\begin{array}{c}\begin{array}{c}\text { Sig. (2- } \\
\text { tailed) }\end{array} \\
\begin{array}{c}\text { Std. Error } \\
\text { Mean }\end{array}\end{array}$} \\
\hline & Mean & $\begin{array}{c}\text { Std. } \\
\text { Deviation }\end{array}$ & $\begin{array}{l}\text { Std. Error } \\
\text { Mean }\end{array}$ & $\begin{array}{l}95 \% \mathrm{Cc} \\
\text { Interv } \\
\text { Diffe }\end{array}$ & $\begin{array}{l}\text { fidence } \\
\text { of the } \\
\text { ence }\end{array}$ & & & \\
\hline $\begin{array}{ll}\text { Pair } 1 & \begin{array}{l}\text { kontrol - } \\
\text { eksperimen }\end{array}\end{array}$ & $19,70444^{-}$ & 6,06034 & 1,01006 & 21,75497 & 17,65392 & $-19,508$ & 32 & ,000 \\
\hline
\end{tabular}

Tabel 6. Hasil Nilai Aspek Afektif Siswa pada Kelas Kontrol Menggunakan Jobsheet

\begin{tabular}{ccccc}
\hline No & Rentang nilai & Kriteria Kepraktisan & Nilai & Frekwensi \\
\hline 1 & $4,2-5,0$ & Sangat Baik & 5 & 0 \\
2 & $3,4-4,2$ & Baik & 4 & 22 \\
3 & $2,6-3,4$ & Cukup & 3 & 10 \\
4 & $1,8-2,6$ & Kurang & 2 & 0 \\
5 & $0-1,7$ & Sangat Kurang & 1 & 0 \\
\hline \multicolumn{7}{r}{} & Jumlah & & 32 \\
\hline
\end{tabular}

Berdasarkan hasil uji-t nilai pretest pada Tabel 5. diperoleh hasil signifikansi dari kedua kelas tersebut sebesar 0,000 yang berartinilainya lebih kecil dari 0,05. Maka dapat disimpulkan bahwa terdapat perbedaan hasil belajar kelas kontrol dengan kelas eksperimen pada mata mata pelajaran Teknik Digital.

\section{Hasil Belajar Aspek Afektif Kelas Kontrol}

Hasil penilaian ranah afektif dilihat melalui pengamatan oleh guru terhadap aspek-aspek keterampilan pada saat proses pembelajaran berlangsung. Aspek penilaian pada ranah afektif adalah: penilaian sikap jujur, minat, konsep diri, toleransi, gotong royong, percaya diri, dan diskusi kelompok. Tabel 6 adalah hasil rangkuman nilai siswa dilihat dari ranah afektif pada kelas kontrol menggunakan menggunakan jobsheet.

Berdasarkan data hasil penilaian pada aspek afektif siswa setelah belajar Teknik Digital,

Tabel 7. Hasil Nilai Aspek Afektif Siswa pada Kelas Eksperimen Menggunakan Perangkat Pembelajaran Teknik Digital

\begin{tabular}{ccccc}
\hline No & Rentang nilai & Kriteria Kepraktisan & Nilai & Frekwensi \\
\hline 1 & $4,2-5,0$ & Sangat Baik & 5 & 14 \\
2 & $3,4-4,2$ & Baik & 4 & 18 \\
3 & $2,6-3,4$ & Cukup & 3 & 0 \\
4 & $1,8-2,6$ & Kurang & 2 & 0 \\
5 & $0-1,7$ & Sangat Kurang & 1 & 0 \\
\hline \multicolumn{4}{r}{} \\
\hline
\end{tabular}

diperoleh data bahwa 22 orang siswa memiliki kriteria baik dan 10 orang siswa memiliki kriteria cukup. Penilaian aspek afektif meliputi: penilaian sikap jujur, minat, konsep diri, toleransi, gotong royong, percaya diri, dan diskusi kelompok.

\section{Hasil Belajar Aspek Afektif Kelas Eksperimen}

Hasil penilaian ranah afektif dilihat melalui pengamatan oleh guru terhadap aspek-aspek keterampilan pada saat proses pembelajaran berlangsung. Aspek penilaian pada ranah afektif adalah: penilaian sikap jujur, minat, konsep diri, toleransi, gotong royong, percaya diri, dan diskusi kelompok. Tabel 7 adalah hasil rangkuman nilai siswa dilihat dari ranah afektif pada kelas eksperimen menggunakan Perangkat Pembelajaran Teknik Digital.
Dari hasil tes yang diberikan pada kelas kontrol dan kelas eksperimen dapat diidentifikasi dan analisis sebagai berikut : 
Berdasarkan data hasil penilaian pada aspek afektif siswa setelah belajar menggunakan Perangkat Pembelajaran Teknik Digital, diperoleh data bahwa 14 orang siswa memiliki kriteria sangat baik dan 18 orang siswa memiliki kriteria baik. Penilaian aspek afektif meliputi: penilaian sikap jujur, minat, konsep diri, toleransi, gotong royong, percaya diri, dan diskusi kelompok. Hal ini membuktikan bahwa proses pembelajaran menggunakan Perangkat Pembelajaran Teknik Digital sangat efektif untuk diterapkan untuk meningkatkan afektif pada siswa dalam pembelajaran Teknik Digital.

\section{Hasil Belajar Aspek Psikomotor Kelas Kontrol}

Hasil penilaian ranah psikomotor dilihat melalui pengamatan oleh guru penilai setelah siswa selesai melakukan dalam pembelajaran Teknik Digital yang diberikan. Aspek penilaian pada ranah psikomotor adalah keterampilan-keterampilan siswa pada saat kegiatan berlangsung. Pengamatan dilakukan pada tahap perencanaan/persiapan dalam pembelajaran Teknik Digital. Berikut ini adalah hasil nilai siswa aspek psikomotor siswa pada kelas kontrol.

Tabel 8. Hasil Nilai Aspek Psikomotor Siswa pada Kelas Kontrol

\begin{tabular}{ccccc}
\hline No & Rentang nilai & Kriteria Kepraktisan & Nilai & Frekwensi \\
\hline 1 & $4,2-5,0$ & Sangat Baik & 5 & 1 \\
2 & $3,4-4,2$ & Baik & 4 & 22 \\
3 & $2,6-3,4$ & Cukup & 3 & 9 \\
4 & $1,8-2,6$ & Kurang & 2 & 0 \\
5 & $0-1,7$ & Sangat Kurang & 1 & 0 \\
\hline \multicolumn{4}{r}{} \\
\hline
\end{tabular}

Berdasarkan data hasil penilaian pada aspek psikomotor setelah pembelajaran konvensional diperoleh 1 orang memiliki kriteria sangat baik, 22 orang yang memilki kriteria baik dan 9 orang memiliki criteria cukup.

\section{Hasil Belajar Aspek Psikomotor Kelas Eksperimen}

Hasil penilaian ranah psikomotor dilihat melalui pengamatan oleh guru penilai setelah siswa selesai melakukan dalam pembelajaran Teknik Digital yang diberikan menggunakan Perangkat Pembelajaran Teknik Digital berbasis proyek. Aspek penilaian pada ranah psikomotor adalah keterampilanketerampilan siswa pada saat kegiatan berlangsung. Pengamatan dilakukan pada tahap perencanaan/persiapan dalam pembelajaran Teknik Digital. Berikut ini adalah hasil nilai siswa aspek psikomotor siswa pada kelas eksperimen menggunakan produk Perangkat Pembelajaran Teknik Digital berbasis proyek.

Tabel 9. Hasil Nilai Aspek Psikomotor Siswa pada Kelas Eksperimen Menggunakan Produk Perangkat Pembelajaran Teknik Digital Berbasis Proyek

\begin{tabular}{ccccc}
\hline No & Rentang nilai & Kriteria Kepraktisan & Nilai & Frekwensi \\
\hline 1 & $4,2-5,0$ & Sangat Baik & 5 & 18 \\
2 & $3,4-4,2$ & Baik & 4 & 14 \\
3 & $2,6-3,4$ & Cukup & 3 & 0 \\
4 & $1,8-2,6$ & Kurang & 2 & 0 \\
5 & $0-1,7$ & Sangat Kurang & 1 & 0 \\
\hline \multicolumn{2}{r}{} \\
\hline
\end{tabular}

Berdasarkan data hasil penilaian pada aspek psikomotor setelah menggunakan Perangkat Pembelajaran Teknik Digital berbasis proyek diperoleh 18 orang memiliki kriteria sangat baik dan 14 orang yang memilki kriteria baik. Hal ini membuktikan bahwa pembelajaran menggunakan Perangkat Pembelajaran Teknik Digital berbasis proyek diterapkan untuk meningkatkan psikomotor siswa.

\section{Penilaian Gabungan Aspek Kognitif, Afektif dan Psikomotor Kelas Kontrol}

Efektivitas Perangkat Pembelajaran Teknik Digital berbasis proyek seperti telah dijelaskan di atas dilihat dari tiga aspek yaitu aspek kognitif, afektif dan psikomotor siswa setelah melaksanakam pembelajaran konvensional. Ketiga aspek penilaian tersebut di atas digabung melalui pengkonversian dan pengolahan nilai dari aspek kognitif, afektif dan psikomotor sehingga diperoleh hasilnya seperti pada Tabel 10. 
Tabel 10. Tabel Hasil Gabungan Penilaian dari Aspek Kognitif, Afektif dan Psikomotor Siswa setelah Pembelajaran Kelas Kontrol

\begin{tabular}{|c|c|c|c|}
\hline \multicolumn{4}{|c|}{ Rekapitulasi Nilai Postest Kelas B (Kelas Kontrol) } \\
\hline Kognitif & Afektif & Psikomotor & K 3 , 1 , A 40\%, S 30\% \\
\hline 74.80 & 70.54 & 72.50 & 72.41 \\
\hline
\end{tabular}

Pada Tabel 10. terlihat bahwa nilai rata-rata Kognitif 74,80. Nilai Afektif 70,54 dan Psikomotor 72,50 dan nilai akhir 72,41 .

\section{Pembahasan}

Penelitian ini menghasilkan Perangkat Pembelajaran Teknik Digital Berbasis Proyek untuk meningkatkan hasil belajar pada mata pelajaran Teknik Digital yang efektivitas.

Uji efektivitas dilakukan dengan cara melihat perbandingan rata-rata hasil belajar siswa pada mata pelajaran Teknik digital.dilihat dari kelas control dan kelas eksperimen baik dari nilai kognitif, afektif dan skpmotor. Nilai rata rata kognitif, afektif dan psikomotor kelas control adalah 72,41 dan kelas eksperimen 83,84. Artinya Perangkat Pembelajaran Teknik Digital Berbasis Proyek efektif untuk meningkatkan hasil belajar siswa.

Hal ini sejalan dengan penelitian Gigin Ginanjar bahwa untuk mengetahui gambaran awal tentang proses maupun hasil pembelajaran menggunakan pembelajaran berbasis proyek, adanya peningkatan proses pembelajaran dari hasil pelaksanaan tindakan, aktivitas siswa dengan model pembelajaran berbasis proyek meningkat dari kategori hampir setengahnya menjadi setengahnya [12]. Selain itu, tes formatif pada setiap siklus terjadi peningkatan. Hal ini menunjukan bahwa tindakan yang dilakukan mampu meningkatkan hasil belajar siswa pada aspek kognitif

\section{KESIMPULAN}

Penelitian pengembangan perangkat pembelajaran Teknik Digital berbasis proyek dikembangkan dengan menggunakan model ADDIE, yang terdiri dari tahap analisis (analysis), perancangan (design), pengembangan (develop) dan evaluasi (evaluate).

Efektivitas perangkat pembelajaran Teknik Digital berbasis proyek yang dikembangkan terhadap siswa secara keseluruhan dapat meningkatkan hasil belajar. Sehingga dapat disimpulkan bahwa penggunaan perangkat pembelajaran Teknik Digital berbasis proyek ini efektif untuk meningkatkan hasil belajar, dibuktikan dengan meningkatnya rata-rata hasil belajar siswa.

\section{DAFTAR PUSTAKA}

[1] Slameto. Belajar Faktor-Faktor yang Mempengaruhinya. Jakarta: Rineka Cipta. 2010.

[2] Departemen Pendidikan dan kebudayaan. 2013. Materi Pelatihan Guru,Jakarta:Badan pengembangan Sumber Daya Manusia Pendidikan dan Kebudayaan dan Menjamin Mutu Pendidikan.

[3] Zuhdan Kun Prasetyo, dkk. 2011. Pengembangan Perangkat Pembelajaran Sains Terpadu Untuk Meningkatkan Kognitif, Keterampilan Proses, Kreativitas serta Menerapkan Konsep Ilmiah Peserta Didik SMP. Program Pascasarjana UNY.

[4] Achmad Rifa'I dan Chatarina Tri Anni. 2012, Psikologi pendidikan.Semarang Unnes Press.

[5] Oemar Hamalik. 2012. Manajemen Pengembangan Kurikulum. Bandung: Remaja Rosdakarya.

[6] Rusman, Kurniawan, Riyana. 2012. Pembelajaran Berbasis Teknologi Informasidan Komunikasi. Jakarta: Rajawali Pers.

[7] Pendit, Putu Laksman dkk. 2006. Perpustakaan Digital: Perspektif Perpustakaan Perguruan Tinggi Indonesia. Jakarta: CV Sagung Seto.

[8] Jalinus, N., Nabawi, R. A. and Mardin, A. The Seven Steps of Project Based Learning Model To Enhance Productive Competences of Vocational Students. $1^{\text {st }}$ International Conference on Technology and Vocational Teacher (ICTVT 2017). Atlantis Press. Advances in Social Science, Education and Humanities research, Volume 102. 2017: 251256.

[9] Jalinus, N., Arwizet, K, Nabawi, R. A. and Ambiyar. Improve Learning Outcomes of Students Through Implementation of The Collaborative Project-Based Learning Model in Thermodynamics. Proceeding the 1st International Conference on Education Innovation. Vol. 1. No. 1. 2017.

[10] N. Jalinus and R. A. Nabawi, "Implementation of the PjBL Model to Enhance Problem Solving Skill and Skill 
Competency of Community College Student," J. Pendidik. Vokasi, vol. 7, no. 3, pp. 304311, 2017.

[11] Sugiyono. Metode Penelitian Tindakan Pendekatan Kuantitatif, Kualitatif, dan $R \& D$. Bandung: CV. Alfabeta. 2011.

[12] Mulyasa. Praktek Penelitian Tindakan Kelas. Bandung: PT Remaja Rosdakarya. 2012.

[13] Ginanjar, A. 2010. Pengembangan Media Pembelajaran Modul Interaktif Mata Kuliah Pemindahan Tanah Mekanik. Surakarta: Universitas Sebelas Maret.

\section{Biodata Penulis}

Yondriadi, lahir di Pilubang 13 Juni 1965. Menyelesaikan SD N 1 Tanjung Medan Tamat tahun 1977, SMP N Bukittinggi Tamat tahun 1981, STM Negeri Bukittinggi Jurusan Teknik Elektronika Tahun 1984, FPTK IKIP Padang Tamat Tahun 1988. Saat ini sedang menyelesaikan S2 di Fakultas Teknik Universitas Negeri Padang. Riwayat Pekerjaan, sebagai Guru SMK N. 1 Lahat pada Jurusan Teknik Audio Video dari tahun 1988 s/d 2015, Kepala SMK Arifbudiman Lahat tahun 2003 s/d 2004, Kepala SMP Negeri 3 Kikim Selatan merangkap Kepala SMP Negeri 4 Kikim Selatan Tahun 2015, Kepala SMK Negeri 1 Merapi Tahun dari 2016 s/d sekarang.

Nizwardi Jalinus lahir Palembang lahir tanggal 22 Agustus 1952. Dosen Jurusan Teknik Mesin Fakultas Teknik Universitas Negeri padang sampai sekarang. Bidang Ilmu: Ilmu Pendidikan - Ilmu Pendidikan Teknologi dan Kejuruan / Pend. Teknologi dan Kejuruan. Kepakaran: Technological Sciences / Mechanical Engineering and Tenchnology.
Nurhasan Syah, lahir Kodya Bukittinggi tanggal 05 Nopember 1960. Dosen Jurusan Teknik Sipil Fakultas Teknik Universitas Negeri Padang sampai sekarang.

Bulkia Rahim, lahir di Sumani Kabupaten Solok Sumatera Barat-Indonesia tahun 1987. Menyelesaikan Diploma tahun 2010 Jurusan Teknik Mesin, menyelesaikan Sarjana Pendidikan Jurusan Pendidikan Otomotif tahun 2013. Menyelesaikan S2 tahun 2016. Berkarir di dunia industri tahun 20062017di PT. Shimano Belakang Muka Kuning Batam-Indonesia. Tahun 2011 bekerja di Jurusan Teknik Mesin Fakultas Teknik Universitas Negeri Padang pada bagian Laboratorium Konversi Energi dan Fenomena dasar Mesin, mulai tahun 2009 bergabung dalam penelitian-penelitian dosen seperti penelitian rancang bangun mesin pengering santan, ikut serta dalam pengabdian masyarakan dosen seperti pelatihan keterampilan teknik pengelasan tingkat lanjut bagi generasi muda putus sekolah dalam rangka pembinaan sikap berwirausaha di kelurahan Lubuk Buaya kecamatan Koto Tangah kota Padang Sumatera Barat, pelatihan penelitian tindakan kelas (PTK). Dosen Teknik Mesin Fakultas Teknik Universitas Negeri Padang dari 2016 - sekarang. 